\title{
The magazine of La Francophonie
}

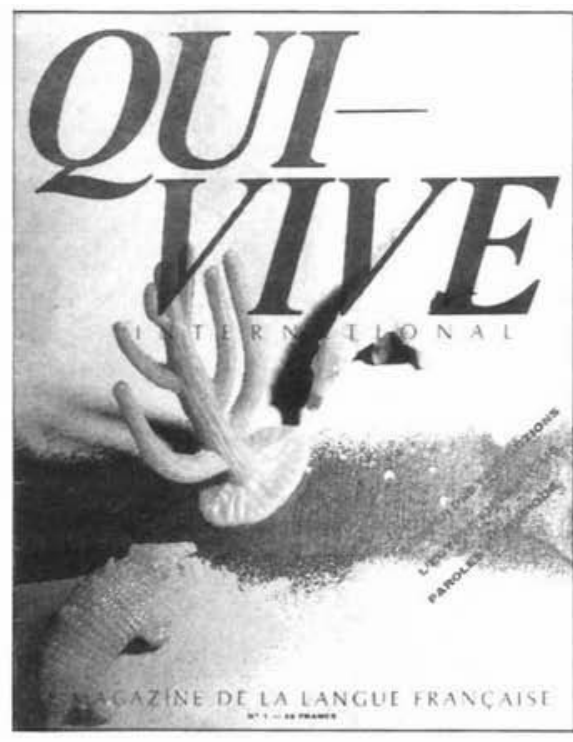

Qui Vive International, now four issues old, calls itself - and is - 'the first magazine of the French language'. Slightly younger than English Today, it serves a similar purpose but in a very different format and style. Where ET is more descriptive than prescriptive, $Q u i$ Vive has shown in every issue to date a concern for the protection of French

\section{AVANT-PROPOS} $L$ e langage est un outil mais aussi un car celui qui perd sa langue perd son âme aussi. Mais pour être compris, encore faut-il quelque chose et que ce quelque chose ait un sens. Aussi évidente que cette remarque puisse paraître, le charabia, I' hexagonal et la langue de bois la démentent à chaque instant. Et la clarté. l'élégance. la concision ont aujourd'hui un parfum étrangement déplacé, subversif presque

C'est de ce haut mal que souffre principalement notre langue, essentiellement de bon aloi, frappée de fausse parole, envenimée de fadaises, retaillée dans sa syntaxe et son vocabulaire pour servir l'insignifiance.

Le divertissement, audiovisuel en particulier, langage à sens unique, assomme nos esprits d'images et de mots fugirifs, voleurs d'attention. Le média imposant sa forme au message, la culture, désarticulée, fait le pantin pour plaire et au ministre, et au citoyen. Le message publicitaire est désormais l'archétype même d'une communication éparpillée. morcellée, absurde autant que multiple.

Et je défendrai l'importance de l'écrit qui reste et qui fait face, et la beauté d'un langage clair. "Parlons français " comme le réclame Alfred Sauvy en p. 58, et nous démontrerons que la modernité, la beauté même, comme l'écrit Thierry de Beaucé n'ont aucune raison de préférer l'apparence américaine.

Elisabeth SCHNEITER

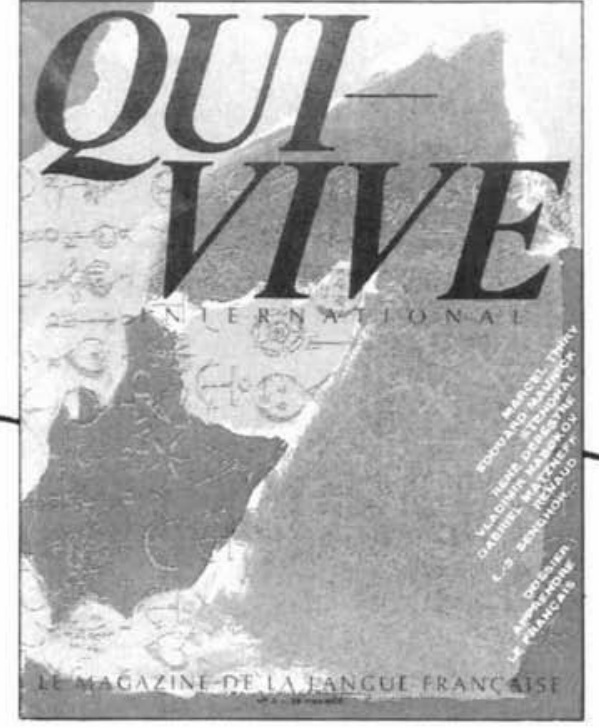

language and culture not only from the enemy without but also from various enemies within. The editor Elisabeth Schneiter (working from 10, boulevard Raspail, 75007 Paris) in her avant-propos of the fourth issue (Sept 86) expresses forcefully the spirit of the magazine:

- that language is a tool, yes, but is also like the stake in a world game of poker, where the loser gives up language, culture and soul

- that jargon and uncouth language threaten clarity of meaning, in an age where elegance and conciseness of expression have about them almost a whiff of subversion

- that good French is assailed by triviality, especially when les médias are at work fragmenting one's attention, and culture jerks like a puppet on a string, trying to serve both the governors and the governed

- that good French can and must survive without succumbing to American influence.

\section{Politics and folklore}

The Editorial Director of Qui Vive is Philippe de St Robert, who in the same issue argues that la Francophonie - the community of French-using nations that is coming into existence - faces two great dangers, la politisation et la folklorisation. As regards politics, he argues that neither the left nor the right has the ultimate say in what French should be and become in the world at large - and insists that the language ought not to be perceived as an extension and tool of the French state or of French identity as such. He points out that for many francophones French is the language of non-alignment. As regards

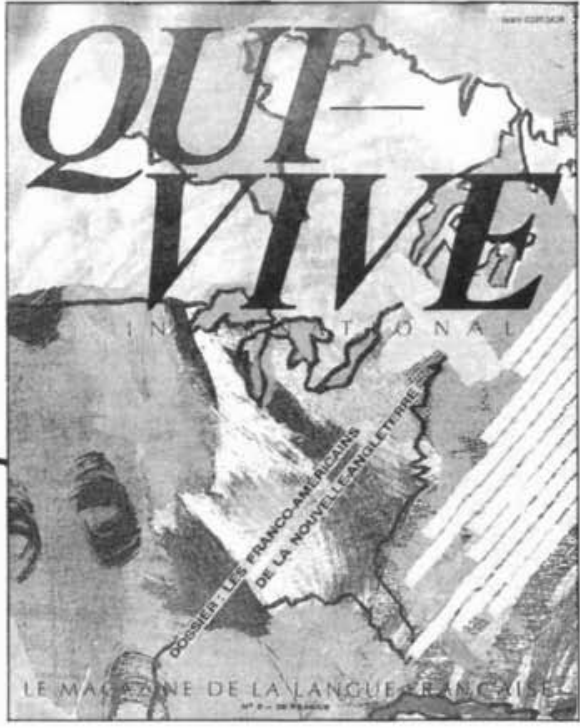

folklore, the world of French speakers is so diverse that its elements should come together as equals, and not as quaint and curious communities. Part of the task of official French organizations for the protection and development of the language should therefore be to operate everywhere in a spirit of co-operation, especially in the creation of a richer vocabulary for all.

\section{A survey}

But do the citizens of France know or care about la Francophonie? In order to find out, QuiVive reports, the Haut Conseil de la Francophonie commissioned a survey to discover how aware and involved French citizens might be. 900 people were interviewed, a cross-section of all ages from 15 upward.

The survey revealed that $68 \%$ of those interviewed knew that la Francophonie was linked with individuals and countries using French regularly, but otherwise their understanding of the implications was weak. Only 3 out of 10 could name a writer in French who was not from France itself and $79 \%$ had no awareness of any organization dedicated to strengthening French as a world language. However, $88 \%$ considered it impcrtant to develop the language, $43 \%$ of whom reckoned that this should be done by the teachers of the language as a priority measure. A remarkable $32 \%$ expressed willingness to give money towards a language foundation for the world community of French. Significantly, however, just over half of the people surveyed $(58 \%)$ saw themselves more as members of a European community (whatever languages might be used) than as members of a global community of French users. 